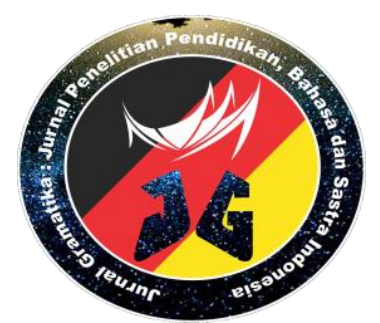

Jurnal Gramatika: Jurnal Penelitian Pendidikan Bahasa dan Sastra Indonesia

(P-ISSN: 2442-8485) (E-ISSN: 2460-6316)

Vol. 5 No. 2. October $2019(236-251)$

http://ejournal.stkip-pgri-sumbar.ac.id/index.php/jurnal-gramatika/index

\title{
CRITICAL DISCUSSION ANALYSIS IN ONLINE NEWS TEMPO. CO ABOUT PILPERS 2019
}

\section{ANALISIS WACANA KRITIS PADA BERITA ONLINE TEMPO. CO TENTANG PILPERS 2019}

\author{
Candra Pramita1), Syahrul Ramadan'), Tressyalina ${ }^{3)}$, Afnita $^{4)}$ \\ 1,2,3,4 Universitas Negeri Padang, Indonesia, \\ candrapramita@student.unp.ac.id, syahrul_r@fbs.unp.ac.id, tressyalina@fbs.unp.ac.id, \\ afnita@fbs.unp.ac.id \\ Submitted: 19-05-2019, Reviewed:12-07-2019, Accepted:01-10-2019 \\ https://doi.org/10.22202/JG.2019.V5i2.3360
}

\begin{abstract}
Discourse analysis on Tempo online media. Co about PILPERS 2019 where a group or person is marginalized in the discourse. The purpose of this study is to describe the use of inclusion theory on political news and see the journalists' impartiality in the 2019 election in Tempo.co online news media. Data collection is done through three stages, (1) reading and understanding the discourse on Tempo's online mass media political news. The May 2019 edition of the Co with the aim of obtaining a clear understanding of the content of the discourse to be studied, (2) marking parts of discourse related to Leeuwen's inclusioan theory, and (3) inventorying sentences in discourses related to Leeuwen's inclusioan theory by sorting and grouping data. Based on the results of the study it can be concluded, Leeuwen's inclusioan theory was found in eight Tempo mass media online news media. The May 2019 edition of Co consists of five of the seven existing theories, namely objectivity, nominations, nominations, identification, assimilation-individualization, and association-dissociation. Of the five Leeuwen inclusioan theories found there were 66 sentences containing Leeuwen's inclusioan theory. So, it can be concluded that in writing news about criminal journalists marginalizing victims. Journalists side with actors or actors.
\end{abstract}

Keywords: Tempo Online News. Co, inclusiaon, Leeuwen, Pilpers 2019.

\begin{abstract}
Abstrak
Analisis wacana pada media massa online Tempo. Co tentang PILPERS 2019 dimana suatu kelompok atau seseorang dimarjinalkan posisinya dalam wacana tersebut. Tujuan penelitian ini adalah mendeskripsikan penggunaan teori inklusi pada berita politik dan melihat tentang keperpihakkan wartawan pada pilpers 2019 dalam berita media massa online Tempo.co. Pengumpulan data dilakukan melalui tiga tahap, (1) membaca dan memahami wacana pada berita politik media massa online Tempo. Co edisi Mei 2019dengan tujuan untuk memperoleh pemahaman yang jelas tentang isi wacana yang akan diteliti, (2) menandai bagian-bagian wacana yang berhubungan dengan teori inclusioan Leeuwen, dan (3) menginventarisasi kalimat dalam wacana yang berhubungan dengan teori inclusioan Leeuwen dengan memilah dan mengelompokkan data. Berdasarkan hasil penelitian dapat disimpulkan, teori inclusioan Leeuwen yang ditemukan dalam delapan berita politik media massa online Tempo. Co edisi Mei 2019 berjumlah lima dari tujuh teori yang ada, yaitu
\end{abstract}


Jurnal Gramatika: Jurnal Penelitian Pendidikan Bahasa dan Sastra Indonesia

(P-ISSN: 2442-8485) (E-ISSN: 2460-6316)

Vol. 5 No. 2. October 2019 (236-251)

http://ejournal.stkip-pgri-sumbar.ac.id/index.php/jurnal-gramatika/index

objektivita-abstraksi, nominasi-kategorisasi, nominasi-identifikasi, asimilasi-individualisasi, dan asosiaso-disosiasi. Dari lima teori inclusioan Leeuwen yang ditemukan terdapat 66 kalimat yang mengandung teori inclusioan Leeuwen. Jadi, dapat disimpulkan dalam menulis berita kriminal wartawan memarjinalkan korban. Wartawan berpihak kepada pelaku atau aktor.

Kata Kunci: Berita Online Tempo. Co, inclusiaon, Leeuwen, Pilpers 2019.

\section{Pendahuluan}

Media massa adalah salah satu bentuk kemajuan teknologi dalam bidang informasi dan komunikasi. Pengaruh media massa berbeda-beda terhadap setiap individu. Hal ini disebabkan karena adanya perbedaan pola pikir, perbedaan sifat yang berdampak pada pengambilan sikap, baik itu kehidupan sosial masyarakat maupun kehidupan sehari-hari. Secara umum media massa adalah sarana penyampaian informasi dari sumber informasi (komunikator) kepada penerima informasi (komunikan). Masuknya informasi oleh media massa membawa dampak perubahan sosial dalam kehidupan masyarakat. Dengan demikian, informasi memiliki kekuatan baik yang membangun dan tidak merusak. Media massa ini terdiri dari media cetak dan media online yang berupa situs web (website) di internet. Media massa cetak seperti Koran dan media massa online seperti website Tempo. Co didalamnya terdapat berbagai macam wacana.

Analisis wacana kritis pada media massa, merupakan bentuk kesimpulan dari sudut pandang yang penulis kemukakan mengenai media massa, yang bersentuhan dengan perihal analisis isi, wacana, dan semiotika. Dilihat dari wujud kekuasaan, bentuk hegemoni serta dampak idiologi dominan yang tersampaikan dalam teks dan wacana. Namun penulis juga mulai memahami bahwa kemampuan masyarakat dalam memilah media massa serta mengartikan makna, menjadi semacam perisai yang membatasi terpaan-terpaan informasi dari berbagai media massa baik online maupun cetak. Penulis dalam hal ini hanya berupaya untuk lebih memahami fungsi serta peran media massa. Ideologi media massa kepada masyarakat sebagai bagian dari alur mediasi pembentukan realitas melalui teks berita.

Informasi yang didapat pembaca dari berita merupakan hasil tulisan dari wartawan berita. Oleh sebab itu, dalam menulis berita wartawan harus menulis berita secara fakta atau penyampai sesuatu apa adanya, karena melalui tulisan yang ditulisnya, pembaca bisa menafsirkan keadaan yang terjadi. Namun kenyataan yang penulis temukan di lapangan tidak semua penulis berita mampu menuliskan berita sesuai dengan fakta, kadang-kadang mereka memasukkan kekuasaan di dalam tulisannya. Kekuasaan di sini maksudnya, jika penulis berita ingin memberitakan orang yang berpengarauh atau berkuasa, ia tidak akan berani menjelek-jelekkan pelaku, karena ia takut akan ditegur. Untuk itu peneliti tertarik untuk melakukan penelitian wacana kristis pada berita media massa online seperti website Tempo. Co.

Sebelum menganalisis teori inclusioan dalam wacana berita politik tentang Pilpers 2019. Seorang pembaca kritis tidak hanya sekedar membaca dan percaya dengan apa yang disampaikan penulis berita, tetapi ia akan mencari tau kebenarannya. Untuk mencari tau kebenarannya diperlukan analisis wacana secara kritis. Baryadi (2002:3) mengatakan analisis wacana adalah sebagai salah satu cabang linguistik yang mengkaji satuan lingual yang berada di atas kalimat. Brown dan Yule (dalam Sumarlan, 2003:13) menyatakan analisis wacana mengkaji bagaimana 
bahasa digunakan. Untuk melihat apakah ada kekuasaan digunakan dalam membuat wacana maka diperlukan analisis wacana kritis.

Fairlough (2003:6) menjelaskan analisis wacana kritis digunakan untuk menganalis hubungan sosial melalui cara yang difokuskan pada elemen-elemen linguistik yang dikemukan untuk menunjukkan penentu yang biasanya terselubung dalam sistem hubungan sosial, serta efek-efek yang terselubung yang mungkin mereka miliki dalam sistem tersebut. Untuk melihat hubungan itu, maka penulis menggunakan teori inclusioan yang dikemukan Leeuwen.

Eriyanto (2009:178) mengatakan menurut Leeuwen ada beberapa strategi wacana ketika seseorang atau kelompok orang ditampilkan dalam teks. Hal ini terbagi dua yaitu Exclusion dan Inclusion. Pada penelitian ini, peneliti hanya memakai teori Inclusion yang akan dijelaskan sebagai berikut. Pertama, Diferensiasi-Indiferensiasi. Indiferensiasi adalah suatu peristiwa atau seorang aktor sosial bisa ditampilkan dalam teks secara mandiri, sebagai suatu peristiwa yang unik atau khas. Diferensiasi adalah suatu peristiwa atau seorang aktor sosial bisa ditampilkan dalam teks secara mandiri, sebagai suatu peristiwa yang unik atau khas tetapi juga bisa dibuat kontras dengan menampilkan peristiwa atau aktor lain dalam teks.

Kedua, Objektivasi-Abstraksi. Objektivasi adalah jumlah suatu demonstrasi mahasiswa dapat dikatakan menunjuk angka yang jelas, sedangkan abstraksi adalah jumlah suatu demonstrasi mahasiswa dapat dikatakan menunjuk angka yang tidak jelas atau dengan membuat suatu abstraki seperti ratusan, ribuan, atau banyak sekali. Ketiga, Nominasi-Kategorisasi. Nominasi adalah pemberitaan mengenai aktor (seseorang/kelompok) atau mengenai suatu permasalahan, yang tidak ditampilkan secara jelas, sedangkan kategorisasi adalah pemberitaan mengenai aktor (seseorang/kelompok) atau mengenai suatu permasalahan yang ditampilkan secara jelas. Keempat, Nominasi-Identifikasi. Strategi wacana ini hampir mirip dengan kategorisasi, yakni bagaimana suatu kelompok, peristiwa, atau tindakan tertentu didefinisikan. Bedanya dalam identifikasi, proses pendefinisian itu dilakukan dengan memberi anak kalimat sebagai penjelas.

Kelima, Determinasi-Indeterminasi. Indeterminasi adalah aktor atau peristiwa disebutkan secara jelas, sedangkan determinasi adalah actor yang tidak disebutkan secara jelas (anonim). Keenam, Asimilasi-Individualisasi. Individualisasi adalah aktor sosial yang diberitakan ditunjukkan dengan jelas kategorinya, sedangkan asimilasi adalah actor sosial yang diberitakan dengan tidak jelas kategorinya. Ketujuh, Asosiasi-Disosiasi. Asosiasi adalah aktor atau suatu pihak tidak ditampilkan sendiri, tetapi dihubungkan dengan kelompok lain yang lebih besar, sedangkan disosiasi adalah aktor atau suatu pihak ditampilkan sendiri.

Penelitian tentang analisis wacana kritis tentang politik telah banyak dilakukan diberbagai negara, seperti di Amerika, Turki, Iran, dan Indonesia. Di Amerika analisis wacana kritis digunakan sebagai konsep menunjukkan bagaimana sikap presiden Obama dengan menganalisis kata-kata yang diujarkannya memalui pidatonya. Pada pidatonya kita bisa hasil dari analisis penelitian ini telah menunjukkan bahwa komponen ideologis utama pidato Obama dapat diringkas menjadi konsep-konsep berikut: pragmatisme, liberalisme, inklusivitas, penerimaan keragaman dan persatuan agama dan etnis. Hasil analisis kata kunci menunjukkan bahwa katakata yang paling menonjol digunakan oleh Obama adalah bangsa, baru dan Amerika, dan 
Jurnal Gramatika: Jurnal Penelitian Pendidikan Bahasa dan Sastra Indonesia

(P-ISSN: 2442-8485) (E-ISSN: 2460-6316)

Vol. 5 No. 2. October $2019(236-251)$

http://ejournal.stkip-pgri-sumbar.ac.id/index.php/jurnal-gramatika/index

dominasi keseluruhan dari kata ganti pribadi kita, yang merupakan bukti persepsi inklusif Obama tentang masyarakat Amerika dan kebutuhan untuk persatuan nasional (Horvath, 2009).

Di Turki, wacana mengacu pada apa yang ditandai oleh penulis melalui suatu teks atau apa teks benar-benar sampaikan kepada pembacanya. Apa pun yang ditularkan melalui teks tertentu dapat membahas poin-poin yang lebih dalam yang merujuk pada ideologis politik serta kekuasaan. Dengan kata lain, wacana didasarkan bagaimana teks berfungsi sebagai makna memanifestasikan atau meresepkan perspektif yang tepat tentang dunia. Pada akhir penelitian, dipahami bahwa Media berperan penting untuk melihat bagaimana penelitian ini diperiksa khususnya bagaimana ideologi dibangun melalui berita utama melalui kerja di dalam kerangka kerja Analisis Wacana Kritis surat kabar. Diamati bahwa di Inggris, Jerman, dan Surat kabar Turki telah memberikan liputan khusus pada berita tentang korban perang Suriah yang memaksa perbatasan Eropa. Secara keseluruhan penggunaan headline biasa adalah praktik maksimal baik di tingkat nasional maupun internasional surat kabar internasional yang memuat media berbahasa Inggris, Jerman, dan Turki. Namun, sementara bagian barat media (Inggris dan Jerman) berfokus pada masalah ini dari sudut pandang risiko yang mungkin dihadapi warga Suriah mungkin dibawa ke Uni Eropa, media Turki berfokus pada masalah ini dari perspektif yang berbeda di yang merupakan tragedi Suriah adalah titik kunci.

Studi keseluruhan dapat diringkas dengan menyarankan bahwa analisis wacana kritis memberi para peneliti peluang untuk menampilkan yang belum ditemukan ideologi atau pesan yang ada dalam teks yang tampaknya sederhana. Penelitian ini telah menyanjikan bagaimana ideologi berfungsi dalam pembentukan berita utama surat kabar dan menemukan bahwa berita utama surat kabar tidak hanya memiliki karakteristik retoris yang sama tetapi juga ideologi tersembunyi tertentu di balik teks. Karena itu, pada pembentukan berita utama, sementara editor media massa barat mendekati menyajikan masalah ini dengan melihat masalah dalam hal bagaimana Eropa dapat menahan arus tinggi Suriah ke dalam persatuan, sedangkan media Turki melihat masalah itu merujuk pada fakta bahwa orang-orang Suriah dalam perjalanan ke Eropa berada dalam kondisi yang sulit (Ulum, 2016).

Di Iran penelitian analisis wacana kritis tentang politik dianalisis pada dua surat kabar harian berbahasa Inggris Los Angeles Times dan Tehran Times dalam hal mewakili negosiasi program nuklir Iran. Hasil penelitian menunjukkan bahwa Los Angeles Times cenderung memanfaatkan Wewenang, Penjelasan, Bukti dan Kontrafaktual diskursif strategi; sedangkan, Tehran Times menggunakan Deskripsi Aktor, Hyperbole, Lexisalisasi, Pengulangan dan Situasi Deskripsi strategi diskursif. Studi banding antara dua surat kabar harian berbahasa Inggris Los Angeles Times dan Tehran Times dalam hal mewakili negosiasi program nuklir Iran. Secara efektif, terungkap bahwa kedua surat kabar tersebut mewakili strategi penafsiran (makna). Faktanya, kedua surat kabar mencoba untuk mewakili perspektif mereka sendiri secara positif dan yang lain negatif. Dengan kata lain, Los Angeles Times menggambarkan politik dan perilaku Amerika Serikat Amerika serta Israel secara positif; Padahal, koran ini menerbitkan artikelnya sedemikian rupa sehingga Iran niat itu menipu dan tidak jujur. Selanjutnya, Tehran Times, dengan nada yang sama, menggambarkan niat Iran dan politik sebagai yang jujur; sedangkan, AS yang menunjukkan perilaku flip-flop. Juga terungkap bahwa Los Angeles Times sangat 
Jurnal Gramatika: Jurnal Penelitian Pendidikan Bahasa dan Sastra Indonesia

(P-ISSN: 2442-8485) (E-ISSN: 2460-6316)

Vol. 5 No. 2. October 2019 (236-251)

http://ejournal.stkip-pgri-sumbar.ac.id/index.php/jurnal-gramatika/index

bergantung pada Otoritas, Penjelasan, Evidentiality dan strategi diskursif kontrafaktual. Lebih jauh, ditemukan bahwa Tehran Times telah dominan digunakan Deskripsi Aktor, Hiperbola, Lexisalisasi, Pengulangan, dan Deskripsi Situasi strategi diskursif. kepercayaan yang dipegang oleh khalayak target dua surat kabar " (Nasab, Zohre, Dowlatabadi, dan Reza, 2015).

Di Indonesia sendiri analisis wacana kritis banyak digunakan untuk melihat bagaimana ideology suatu media massa baik cetak maupun elektronik. Analisis wacana kritis pada berita politik yang dilakukan oleh Faridi (2014) yang berjudul Analisis wacana kritis teks berita politik dalam Koran radar madura menjelang pemilu legislatif, hasil penelitian ini wartawan koran radar madura masalah reprensentasi menjadi isu utama dalam beritanya. Reprensentasi kosakata dan tatabahasa pada berita tersebut menimbulkan asosiasi tertentu untuk menggambarkan suatu peristiwa atau realitas di kategorikan (klasifikasi, marjinalisasi, dan pertarungan wacana) ke dalam teks berita. Representasi kosakata metafora yang digunakan wartawan untuk menentukan apakah realitas itu dimaknai positif atau negatif. Suharyo (2014) menyatakan pada hasil penelitiannya menunjukkkan bahwa secara umum kedua surat kabar ini berusaha bersifat netral dan berimbang, akan tetapi ketimpangan tidak dapat dihindarkan, dimana Suara Merdeka dari dimensi kekuasaan lebih dominan sehingga pihak pemerintahan dimarjinalkan. Sedangkan kompas lebih objektif dan netral.

Jamaludin (2016) melalui penelitiannya mengungkapkan bahwa berita politik Pilgup Sumatera Barat periode 2016-2021 pada media online portal Harian Singgalang tidak menunjukkan adanya praktik kekuasaan dengan memberikan citra baik pada satu pihak dengan memarjinalkan pihak satunya. Pada struktur teks yang dianalisis dengan teori Van Dijk, wartawan sama-sama mendominasi setiap pasangan cagup sehingga terciptanya kesimbangan pencitraan setiap calon pilgub. Queen (2015) pada penelitiannya tentang analisis wacana kritis pada surat kabar Kaltim pos dengan menggunakan teori Van Dijk terlihat jelas bahwa Kaltim Pos tidak bersifat netral melainkan memihak satu pihak yaitu pihak KPK dan memarjinalkan pihak Polri.

Di Indonesia dari hasil penelitian menunjukkan bahwa teori inklusi Leeuwen banyak digunakan pada berita kriminal, dilihat bagaimana wartawan memarjinalkan korban atau pelaku dengan cara memihak dan memarjinalkan pihak lain. Hasil penelitian Alfianika (2016) bahwa berita pada Koran Posmetro Padang edisi Mei 2013 dalam menulis berita kriminal dengan tema pencurian wartawan tidak memarjinalkan korban dan dalam membuat judul berita wartawan menyembunyikan actor dengan menggunakan kalimat pasif. Sejalan dengan penelitian Alfianika, menggunakan teori inklusi Leeuwen, Sari (2017) menyatakan bahwa analisis yang dilakukan pada berita kriminal di surat kabar Posmetro Padang tidaklah netral dimana satu pihak memarjinalkan phak lain dengan mengungulkan pihak jajaran direktorat reserse narkoba polda sumbar dan memarjinalkan pihak lain yaitu supir truk yang bernama Indra Jaya. Selain pada berita kriminal teori inclusion leeuwen juga digunakan untuk menganalisis berita politik.

Silitonga dan Oktavia (2016) mengemukankan berita yang ditulis wartawan Harian Padang Ekspres itu tidak netral dimana wartawan dalam menulis tajuk wacana dan berita politik dengan cara memarjinalkan kelompok lain dan membuat berita baik pada suatu pihak dengan memburukkan pihak lainnya. Kekuasaan sangat berperan penting pada penulisan berita tersebut. 


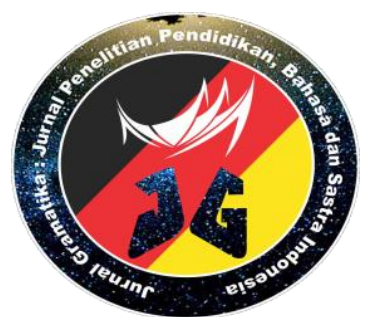

Jurnal Gramatika: Jurnal Penelitian Pendidikan Bahasa dan Sastra Indonesia

(P-ISSN: 2442-8485) (E-ISSN: 2460-6316)

Vol. 5 No. 2. October $2019(236-251)$

http://ejournal.stkip-pgri-sumbar.ac.id/index.php/jurnal-gramatika/index

Rilma (2019) pada penelitiannya yang berjudul Strategi Pemberitaan Online Nasional Tentang Kasus tercecernya KTP Elektronik (analisis teori van leeuwen) menjelaskan berita online yang terdapat pada media online Vivanew.com, Detiknews.com, Kompas.com, Metrones.com, dan Sindonews.com cenderung actor dikeluarkan dan disembunyikan dalam teks berita wartawan menggunakan inklusi dan eksklusi. Dari cara wartawan menyembunyikan actor ini bisa kita lihat bahwa berita online nasional lebih memihak kemementrian dalam negeri yang disalahkan dalam kasus ini.

Penelitian ini berbeda dengan penelitian terdahulu, penelitian ini akan mengkaji wacana kritis dari sudut pandang Inklusi Theo Van Leeuwen. Teks-teks berita politik yang menjadi objek dalam penelitian ini diambil dari surat kabar online Tempo. Co edisi Mei 2019. Dalam teks berita tersebut, penggunaan strategi wacana inklusi terlihat dengan jelas karena wartawan mempresentasikan peristiwa secara akurat dan menyebutkan pelaku sosial yang terkait di dalam topik pemberitaan tersebut. Untuk mengungkapkan maksud dari berita, dapat dilakukan dengan menempatkan diri pada posisi wartawan dengan mengikuti struktur makna dari wartawan sehingga bentuk distribusi dan produksi ideologi politik serta kekuasaan di dalam berita politik tentang pilpers 2019 dapat diketahui. Jadi, wacana dilihat dari segi hubungan kekuasaan terutama dalam pembentukan subjek.

Penelitian ini memiliki ciri khas tersendiri yang membedakannya dari penelitian sejenis yang disampaikan di atas. Penelitian ini mengambil topik bahasan dibidang politik tentang pilpers 2019. Yaitu berkaitan dengan capres nomor urut 01 dan 02. Perbedaan komponen dalam penelitian ini diharapkan dapat lebih menyempurnakan hasil penelitian-penelitian yang sudah pernah dilakukan sebelumnya. Rumusan masalah pada penelitian ini ialah mendeskripsikan penggunaan teori inklusi Leuween pada berita online dan melihat bagaimana keberpihakkan wartawan menulis berita dengan memarjinalkan suatu kelompok atau seseorang pada berita yang ditulisnya.

Berdasarkan pemaparan di atas, penelitian ini memiliki tujuan, yaitu mendeskripsikan penggunaan teori inklusi pada berita politik dan melihat tentang keperpihakkan wartawan pada pilpers 2019 dalam berita media massa online Tempo.co dengan memarjinalkan kelompok tertentu yang menguntungan kelompok lainnya.

\section{Metode Penelitian}

Jenis penelitian ini adalah penelitian kualitatif dengan menggunakan metode deskriptif. Mardalis (2009:26) menjelaskan penelitian deskriptif bertujuan untuk mendeskripsikan apa-apa yang saat itu berlaku. Dalam penelitian ini metode deskriptif ini digunakan untuk melihat, mendeskripsikan dan menganalisis data yang berhubungan dengan inclusioan teori Leeuwen dalam wacana tulis dengan tema berita politik tentang Pilpers 2019 di media massa online Tempo. Co edisi Mei 2019.

Penelitian ini menggunakan metode analisis wacana kritis, dan teknik analisis dan interpretasi data inclusion Leeuwen. Data yang digunakan dalam penelitian ini adalah frasa, klausa, dan kalimat yang berkaitan dengan inclusion teori Leeuwen dalam wacana politik tentang Pilpers 2019 di media massa online Tempo. Co edisi Mei 2019. Hal ini dikarenakan data 
penelitian ini berupa dokumen tertulis yang terdapat dalam sebuah media massa online Tempo .co. Hal pertama yang dilakukan dalam proses pengumpulan data penelitian ini adalah membaca secara cermat setiap berita yang telah dikumpulkan berdasarkan rentang waktu yang telah ditetapkan. Pembacaan data secara cermat ini bertujuan untuk menentukan ada tidaknya strategi inklusi yang terkandung dalam wacana berita tersebut. Hal yang dilakukan selanjutnya, yaitu mencatat data-data yang mengandung inklusi. Setelah dilakukan pencatatan data, data tersebut kemudian dianalisis dengan melewati tiga tahapan analisis data dalam penelitian deskriptif kualitatif, yaitu (1) pereduksian data, (2) penyajian data, dan (3) penarikan simpulan/pembuktian.

Sumber data penelitian ini adalah media massa online Tempo. Co edisi Mei 2019 yang bertema berita politik tentang Pilpers 2019. Intrumen penelitian ini adalah peneliti sendiri dan dibantu oleh instumen pendukung lainnya, seperti format inventarisasi, buku-buku dan jurnaljurnal mengenai inclusion teori Leeuwen.

\section{Hasil dan Pembahasan}

Penggunaan Teori Inclusion Leeuwen dalam Berita politik tentang Pilpers 2019 di media massa online Tempo. Co edisi Mei 2019

Teori inclusion Leeuwen yang ditemukan pada delapan berita politik tentang Pilpers 2019 media massa online Tempo. Co edisi Mei 2019 adalah objektivita-abstraksi, nominasikategorisasi, nominasi-identifikasi, asimilasi-individualisasi, dan asosiasi-disosiasi. Dari enam teori inclusioan Leeuwen yang ditemukan terdapat 33 kalimat yang mengandung teori inclusioan Leeuwen. Uraian masing-masing teori inclusioan Leeuwen yang ditemukan dalam delapan berita politik tentang Pilpers 2019 media massa online Tempo. Co edisi Mei 2019 untuk lebih jelasnya perhatikan tabel dibawah ini.

Tabel 1. Penggunaan teori Inclusioan Leeuwen dalam delapan berita politik tentang Pilpers 2019

\begin{tabular}{clc}
\hline No & \multicolumn{1}{c}{ Temuan } & Jumlah \\
\hline 1 & Objektivasi (Obj) & 10 \\
& Abstraksi (abs) & 4 \\
2 & Nominasi (Nom) & 0 \\
& Kategorisasi (Kat) & 20 \\
3 & Nominasi (Nom) & 0 \\
& Identifikasi (Inden) & 10 \\
4 & Asimilasi (Asi) & 0 \\
& Individualisasi (Indiv) & 15 \\
5 & Asosiasi (Aso) & 5 \\
& Disosiasi (Dis) & 2 \\
\hline & Jumlah & 66 \\
\hline
\end{tabular}




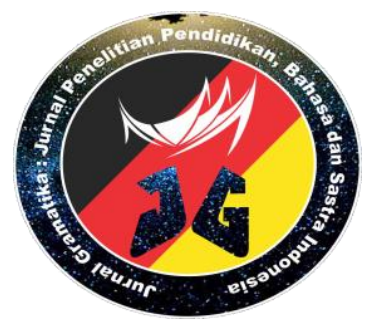

Jurnal Gramatika: Jurnal Penelitian Pendidikan Bahasa dan Sastra Indonesia

(P-ISSN: 2442-8485) (E-ISSN: 2460-6316)

Vol. 5 No. 2. October $2019(236-251)$

http://ejournal.stkip-pgri-sumbar.ac.id/index.php/jurnal-gramatika/index

Penjelasan lebih lanjut tentang temuan diatas akan dibahas satu persatu secara rinci dan jelas sebagai berikut:

\section{a. Objektivasi (Obj) - Abstraksi (abs)}

Objektivasi adalah jumlah suatu demonstrasi mahasiswa dapat dikatakan menunjuk angka yang jelas, sedangkan abstraksi adalah jumlah suatu demonstrasi mahasiswa dapat dikatakan menunjuk angka yang tidak jelas atau dengan membuat suatu abstraki seperti ratusan, ribuan, atau banyak sekali, (Leeuwen, dalam Eriyanto 2009:181). Penggunaan teori objektivasi (Obj)-obstraksi (Abs) Leeuwen yang ditemukan dalam delapan berita politik tentang Pilpers 2019 media massa online Tempo. Co edisi Mei 2019 berjumlah 14 kalimat, yaitu 10 kalimat dari teori objektivitas dan 4 kalimat dari teori abstraksi. Hal itu dapat dibuktikan dari beberapa kutipan di bawah ini.

"Anggota tim lainnya, Laode Kamaludin mengklaim sampai pada siang tadi, Prabowo Sandiaga unggul dengan angka 54,24 persen. Adapun lawannya, Jokowi - Ma'ruf Amin 44,14 persen. Adapun sisanya adalah suara tidak sah. Data ini menurut dia, merupakan hasil penghitungan suara oleh BPN dari 51 persen TPS.". (judul berita BPN Klaim Prabowo Unggul 54,24 Persen)

Kutipan kalimat di atas merupakan contoh objektifitas, karena pada kalimat di atas terdapat kata-kata dengan memberi petunjuk yang jelas. Seperti kalimat 44,41 persen suara hasil perhitungan suara oleh BPN dari 51 persen TPS yang jelas dirincikan secara jelas.

Pada pembahasan dari hasil temuan ini diperoleh bahwa wacana yang disajikan wartawan dengan jelas agar kita bisa melihat bahwa wartawan menyampaikan berita bersifat netral dan jelas sehingga tidak adanya praanggapan yang nantinya menimbulkan persepsi yang berbeda-beda dari masyarakat. Dengan mencantumkan angka yang jelas wartawan menyampaikan secara objektif. Dimana pada bagian ini jelas wartawan berusaha memberikan informasi yang jelas kepada masyarakat. Sesuai dengan teori yang menyatakan bahwa Objektivasi adalah jumlah suatu demonstrasi mahasiswa dapat dikatakan menunjuk angka yang jelas (Eriyanto 2009:181).

"Di Pilkada Jawa Timur 2018, suara sah sebanyak 19,5 juta suara. Sementara pada pilpres 2019 di Jawa Timur, suara sah 24,7 juta suara. Kubu Prabowo menyebut kenaikan suara sebanyak 5,2 juta tersebut sebagai penggelembungan." (judul berita Kubu Jokowi Buka 4 Kejanggalan Data Kecurangan Versi Kubu Prabowo)

Kutipan kalimat di atas merupakan contoh objektifitas, karena pada kalimat diatas terdapat kata-kata dengan memberi petunjuk yang jelas. Kata 19,5 juta suara dan 24,7 juta suara menunjukkan bukti yang jelas tidak lagi abstrak. Pada pembahasan dari hasil temuan ini diperoleh bahwa wartawan mencantumkan angka agar masyarakat dapat memahami dengan jelas berapa jumlah suara yang masuk dan wartawan disini bersifat objektif. Wartawan dengan mencamtumkan jumlah angka yang masuk ini untuk menunjukkan perkembangan suara yang diterima oleh kubu capres nomor urut 02, dari bahasa yang digunakan meski wartawan bersikap objektif dengan mengemukankan berapa suara tapi dari segi wacana yang terdapat dalam berita 


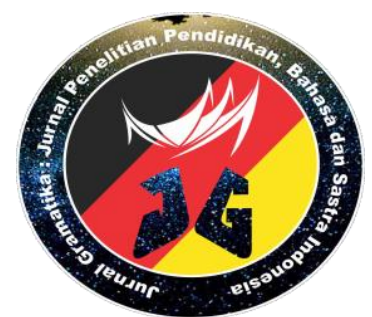

Jurnal Gramatika: Jurnal Penelitian Pendidikan Bahasa dan Sastra Indonesia

(P-ISSN: 2442-8485) (E-ISSN: 2460-6316)

Vol. 5 No. 2. October $2019(236-251)$

http://ejournal.stkip-pgri-sumbar.ac.id/index.php/jurnal-gramatika/index

ini tetap memojokkan pihak capres no urut 02 , dan membuat pihak 01 menjadi korban akan peristiwa kecurangan suara.

"Ancaman boikot pajak juga menjadi viral dan ramai diperbincangkan oleh netizen di sejumlah media sosial. Ada yang khawatir ajakan boikot pajak hanya akan berdampak buruk terhadap Negara”. (Judul berita Kubu Prabowo Serukan Boikot Pajak, Pengamat: Konyol)

Kutipan kalimat di atas merupakan contoh abstraksi, karena pada kalimat diatas terdapat kata-kata dengan tidak memberi petunjuk yang jelas. Seperti kata ramai oleh netizen, kata ramai ini tidak jelas seberapa banyak dan kata netizen juga merupakan kata yang abstrak atau tidak jelas siapa mereka. Wartawan menyampaikan bahwa banyak netizen yang berpandangan buruk pada capres no urut 02, wartawan dengan gambling menyampaikan keburukkan no urut 02 dengan bahasa yang digunakan dan judul yang digunakan sudah jelas bersikap subjektif dan memarjinalkan satu pihak demi membuat citra baik pada pihak yang lainnya.

\section{b. Nominasi (Nom) - Kategorisasi (Kat)}

Nominasi adalah pemberitaan mengenai aktor (seseorang/kelompok) atau mengenai suatu permasalahan, yang tidak ditampilkan secara jelas, sedangkan kategorisasi adalah pemberitaan mengenai aktor (seseorang/kelompok) atau mengenai suatu permasalahan, yang ditampilkan secara jelas, (Leeuwen dalam Eriyanto 2009:182). Penggunaan teori nominasi (Nom)kategorisasi (Kat) Leeuwen yang ditemukan dalam delapan berita politik tentang Pilpers 2019 media massa online Tempo. Co edisi Mei 2019 berjumlah 20 kalimat, yaitu 20 kalimat dari teori kategorisasi. Hal itu dapat dibuktikan dari beberapa kutipan di bawah ini.

"Ajakan Wakil Ketua Umum Gerindra Arief Poyuono kepada pendukung Prabowo Subianto - Sandiaga Uno untuk memboikot pajak sebagai bentuk ketidakpercayaan terhadap pemerintah baru hasil Pemilihan Presiden 2019 dinilai sebagai hal yang konyol.”. (judul berita Kubu Prabowo Serukan Boikot Pajak, Pengamat: Konyol)

Kutipan kalimat di atas merupakan contoh kategorisasi, karena pada kalimat di atas aktor ditampilkan secara jelas. Aktor disebut namanya dengan jelas yaitu Arief Poyuono Wakil Ketua Umum Gerindra. Dari temuan ini bisa kita bahas lebih lanjut, bahwa wartawan disini bersifat netral karena apa yang ditulis wartawan kebanyakkan dijelaskan siapa actor dan apa yang dikatakan actor. Wartawan disini dengan jelas tidak memihak siapapun sehingga masyarakatlah yang berpikir kritis dan menilai mana yang salah dan mana yang benar.

"Calon presiden nomor urut 02 Prabowo Subianto menyampaikan pidato politik dalam Simposioum Nasional Kecurangan Pemilu 2019 di Hotel Grand Sahid, Jakarta Pusat, Selasa, 14 Mei 2019”. (judul berita Prabowo Menolak Penghitungan Pemilu Curang, Ini Pidato Lengkapnya). 




Jurnal Gramatika: Jurnal Penelitian Pendidikan Bahasa dan Sastra Indonesia

(P-ISSN: 2442-8485) (E-ISSN: 2460-6316)

Vol. 5 No. 2. October $2019(236-251)$

http://ejournal.stkip-pgri-sumbar.ac.id/index.php/jurnal-gramatika/index

Kutipan kalimat di atas merupakan contoh kategorisasi karena pada kalimat di atas aktor ditampilkan dengan menyebutkan nama dan kategori sosialnya, yaitu Prabowo Subianto Calon presiden nomor urut 02 . Jika disebutkan kategori sosial berarti itu termasuk kepada kategorisasi. Pada pembahasan dari data diatas kita bisa melihat bahwa wartawan dengan jelas menyampaikan bahwa no urut 02 tidak terima dengan hasil perhitungan pemilu, dengan menyampaikan kategorisasi wartawan dengan tegas menyampaikan secara jelas dan wartawan disini berusaha bersifat netral agar tidak ada pihak yang dimarjinalkan. Meski demikian kalau kita teliti lebih lanjut dari bahasa yang digunakan sebenarnya wartawan sudah jelas bahwa wartawan secara tidak langsung memarjinalkan kelompok lain yaitu capres no urut 01 Jokowi-Ma'aruf. Pada teks berita ini dijelaskan bahwa pihak capres no urur 02 menolak perhitungan suara karna adanya kecurangan pada pemilu kali ini. Pihak capres no urut 02 memberitakan pidato yang isinya memarjinalkan pihak no urut 01 .

"Kubu calon presiden inkumben Joko Widodo atau Jokowi menantang kubu Prabowo Subianto beradu data hasil pemilihan umum di Komisi Pemilihan Umum (KPU). Tantangan ini dilakukan menyusul simposium mengungkap fakta-fakta kecurangan pilpres 2019 yang digelar Badan Pemenangan Nasional (BPN) Prabowo-Sandi di Hotel Grand Sahid, Jakarta, Selasa 14 Mei 2019”. (judul berita Kubu Jokowi Tantang Kubu Prabowo Adu Data C1 di KPU )

Kutipan kalimat di atas merupakan contoh kategorisasi karena pada kalimat di atas aktor ditampilkan dengan menyebutkan nama dan kategori sosialnya, yaitu Joko Widodo calon presiden inkumben. Jika disebutkan kategori sosial berarti itu termasuk kepada kategorisasi. Dari data temuan diatas bisa kita lihat bahwa wartawan dalam menulis berita menyampaikan secara jelas nama actor dan wartawan bersifat netral dengan tidak memihak pihak lain demi keuntungan pihak lainnya. Pada wacana berita yang ditulis wartawan tidak menyembunyikan actor tetapi dengan jelas menyebutkan nama serta profesi actor itu, hal ini dikarenakan wartawan berusaha menyampaikan berita dengan jelas kepada masyarakat.

\section{c. Nominasi (Nom) - Identifikasi (Inden)}

Strategi wacana ini hampir mirip dengan kategorisasi, yakni bagaimana suatu kelompok, peristiwa, atau tindakan tertentu didefinisikan. Bedanya dalam identifikasi, proses pendefinisian itu dilakukan dengan memberi anak kalimat sebagai penjelas, (Leeuwen dalam Eriyanto, 2009:184). Penggunaan teori nominasi (Nom)-identifikasi (Inden) Leeuwen yang ditemukan pada delapan berita politik tentang Pilpers 2019 media massa online Tempo. Co edisi Mei 2019 berjumlah 10 kalimat, yaitu 10 kalimat teori identifikasi. Hal itu dapat dibuktikan dari beberapa kutipan di bawah ini.

"Komisioner Komisi Pemilihan Umum atau KPU Viryan Aziz menyayangkan keputusan kubu Prabowo yang menarik saksi untuk perhitungan suara. Viryan mengatakan, penarikan itu menjadikan kubu 02 kehilangan kesempatan menyaksikan proses 


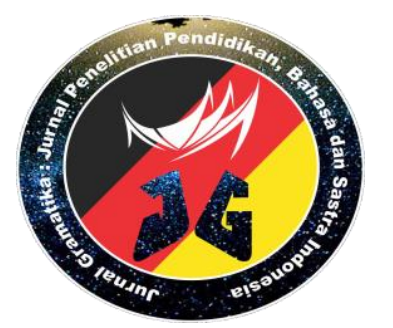

Jurnal Gramatika: Jurnal Penelitian Pendidikan Bahasa dan Sastra Indonesia

(P-ISSN: 2442-8485) (E-ISSN: 2460-6316)

Vol. 5 No. 2. October $2019(236-251)$

http://ejournal.stkip-pgri-sumbar.ac.id/index.php/jurnal-gramatika/index

rekapitulasi suara di KPU” (judul berita Saksi Prabowo Ditarik, KPU: Hilang Kesempatan Lihat Rekapitulasi)

Kutipan kalimat di atas merupakan contoh identifikasi, karena pada kalimat diatas aktor ditampilkan secara jelas. Actor dijelaskan bernama Viryan Aziz seorang Komisioner Komisi Pemilihan Umum. Data yang disampaikan secara jelas agar tidak adanya pihak yang dirugikan dan merasa di marjinalkan oleh tulisan wartawan ini, pada kutipan ini jelas disebutkan dengan jelas nama actor serta siapakah actor yang dibicarakan pun dijelaskan seperti nama dan profesi atau jabatan actor. Sehingga tidak terjadikanya kesalahpahaman publik.

"Juru bicara Badan Pemenangan Nasional Prabowo Subianto-Sandiaga Uno, Andre Rosiade menanggapi putusan Badan Pengawas Pemilu atau Bawaslu yang menyatakan Komisi Pemilihan Umum melanggar tata cara aturan sistem informasi perhitungan suara (Situng). Putusan itu sekaligus menjadi jawaban atas gugatan yang dilayangkan BPN Prabowo sebelumnya”. (judul berita Gugatan Diputus Bawaslu, Begini Komentar Kubu Prabowo)

Kutipan kalimat di atas merupakan contoh identifikasi, karena pada kalimat diatas aktor ditampilkan secara jelas. Actor dijelaskan bernama Andre Rosiade seorang Badan Pemenangan Nasional Prabowo Subianto-Sandiaga Uno. Sama halnya dengan kutipan di atas bahwa wartawan berusaha bersifat netral dengan mengambarkan secara jelas siapa actor serta apa profesi actor. Hal ini dilakukan wartawan agar tidak ada pihak yang dirugikan, pada teks berita ini wartawan hanya sebagai wadah penyampaian informasi yang didapatkannya melalui sumber tanpa memihak dan menjatuhkan pihak lainnya.

\section{d. Asimilasi (Asi) - Individualisasi (Indiv)}

Individualisasi adalah aktor sosial yang diberitakan ditunjukkan dengan jelas kategorinya, sedangkan asimilasi adalah aktor sosial yang diberitakan dengan tidak jelas kategorinya, (Leeuwen dalam Eriyanto, 2009:187). Penggunaan teori asimilasi (Asi)-individualisasi (Indiv) Leeuwen yang ditemukan pada delapan berita politik tentang Pilpers 2019 media massa online Tempo. Co edisi Mei 2019 berjumlah 15 kalimat, yaitu 15 kalimat dari teori individualisasi. Hal itu dapat dibuktikan dari beberapa kutipan di bawah ini.

"Kubu calon presiden inkumben Joko Widodo atau Jokowi menanggapi fakta-fakta kecurangan pilpres 2019 versi Badan Pemenangan Nasional (BPN) Prabowo-Sandi yang diungkap dalam sebuah acara simposium di Hotel Grand Sahid, Jakarta, Selasa 14 Mei 2019.”. (judul berita Kubu Jokowi Buka 4 Kejanggalan Data Kecurangan Versi Kubu Prabowo) 


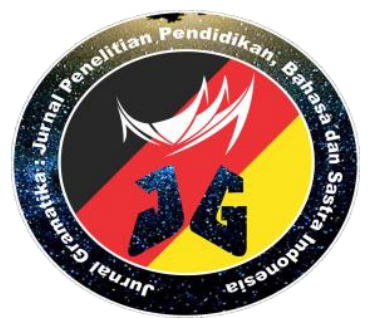

Jurnal Gramatika: Jurnal Penelitian Pendidikan Bahasa dan Sastra Indonesia

(P-ISSN: 2442-8485) (E-ISSN: 2460-6316)

Vol. 5 No. 2. October $2019(236-251)$

http://ejournal.stkip-pgri-sumbar.ac.id/index.php/jurnal-gramatika/index

Kutipan kalimat di atas merupakan contoh individualisasi, karena pada kalimat di atas aktor ditampilkan secara jelas. Aktor ditampilkan dengan menyebutkan namanya yaitu Joko Widodo.

"Menurut Juru Bicara TKN Jokowi-Ma'ruf, Arya Sinulingga, data-data yang disuguhkan kubu Prabowo itu tidak valid sama sekali. Setidaknya ada empat poin yang disoroti Arya”. (judul berita Kubu Jokowi Buka 4 Kejanggalan Data Kecurangan Versi Kubu Prabowo)

Kutipan kalimat di atas merupakan contoh indivudulisasi, karena pada kalimat di atas aktor ditampilkan secara jelas. Aktor ditampilkan dengan menyebutkan namanya yaitu Arya Sinulingga. Pada data bisa kita lihat bersifat individual dimana pada berita no urut 01 mendominasi isi teks berita sehingga dengan jelas berita ini menguntungkan pihak 01 dan merugikan pihak 02, wartawan dengan jelas dan tegas berusaha bersifat netral akan tetapi tidak bisa menghindari bahwa dengan tulisan ini pihak 02 dirugikan. aktor sosial yang diberitakan ditunjukkan dengan jelas kategorinya baik itu nama serta profesinya, pada wacana berita yang ditulis wartawan itu juga mengunakan frasa, klausa, dan kalimat yang menampilkan actor seperti kalimat berikut ini "Menurut Juru Bicara TKN Jokowi-Ma'ruf, Arya Sinulingga, data-data yang disuguhkan kubu Prabowo itu tidak valid sama sekali'. Pada kalimat ini jelas sekali aktornya ialah Arya Sinulingga seorang juru bicara TKN Jokowi.

\section{e. Asosiasi (Aso)-Disosiasi (Dis)}

Asosiasi adalah aktor atau suatu pihak tidak ditampilkan sendiri, tetapi dihubungkan dengan kelompok lain yang lebih besar, sedangkan disosiasi adalah aktor atau suatu pihak ditampilkan sendiri, (Leeuwen dalam Eriyanto, 2009:189). Penggunaan teori asosiasi (Aso)disosiasi (Dis) Leeuwen yang ditemukan pada pada delapan berita politik tentang Pilpers 2019 media massa online Tempo. Co edisi Mei 2019 berjumlah 7 kalimat, yaitu 5 kalimat dari teori asosiasi dan 2 kalimat teori disasosiasi. Hal itu dapat dibuktikan dari beberapa kutipan di bawah ini.

"Kubu calon presiden inkumben Joko Widodo atau Jokowi menanggapi fakta-fakta kecurangan pilpres 2019 versi Badan Pemenangan Nasional (BPN) Prabowo-Sandi yang diungkap dalam sebuah acara simposium di Hotel Grand Sahid, Jakarta, Selasa 14 Mei 2019. Menurut Juru Bicara TKN Jokowi-Ma'ruf, Arya Sinulingga, data-data yang disuguhkan kubu Prabowo itu tidak valid sama sekali”. (judul berita Kubu Jokowi Buka 4 Kejanggalan Data Kecurangan Versi Kubu Prabowo)

Kutipan kalimat di atas merupakan contoh asosiasi, karena pada kalimat di atas aktor dihubungkan dengan aktor lain. Aktor "Joko Widodo" yang menanggapi fakta-fakta kecurangan Pilpers 2019, dihubungkan dengan aktor Arya Sinulingga sebagai juru bicara TKN JokowiMa'ruf yang mendukung pendapat aktor pertama. 




Jurnal Gramatika: Jurnal Penelitian Pendidikan Bahasa dan Sastra Indonesia

(P-ISSN: 2442-8485) (E-ISSN: 2460-6316)

Vol. 5 No. 2. October $2019(236-251)$

http://ejournal.stkip-pgri-sumbar.ac.id/index.php/jurnal-gramatika/index

"Calon presiden nomor urut 02 Prabowo Subianto menyampaikan pidato politik dalam Simposioum Nasional Kecurangan Pemilu 2019 di Hotel Grand Sahid, Jakarta Pusat, Selasa, 14 Mei 2019". (judul berita Prabowo Menolak Penghitungan Pemilu Curang, Ini Pidato Lengkapnya).

Kutipan kalimat di atas merupakan contoh disasosiasi, karena pada kalimat di atas aktor ditampilkan sendiri dan tidak dihubungkan dengan aktor lain. Dari hasil temuan dan pembahasan di atas dapat penulis simpulkan dalam menulis berita politik tentang pilpers 2019 wartawan tidak bersikap netral karena dari temuan data banyak yang bersifat subjektif bukannya objektif dimana wartawan memihak satu pihak dan berusaha menjatuhkan pihak lain secara tidak langsung. Hal itu terbukti dari wartawan menuliskan nama aktor dan menjelaskan apa yang dilakukan actor dalam menyudutkan actor lain, selain itu wartawan juga menjelaskan pihak-pihak yang akan terlibat seperti lembaga-lembaga yang terkait dalam pilpers 2019. Hal itu dapat dibuktikan dari kutipan di bawah ini.

"Kubu calon presiden inkumben Joko Widodo atau Jokowi menanggapi fakta-fakta kecurangan pilpres 2019 versi Badan Pemenangan Nasional (BPN) Prabowo-Sandi yang diungkap dalam sebuah acara simposium di Hotel Grand Sahid, Jakarta, Selasa 14 Mei 2019. Menurut Juru Bicara TKN Jokowi-Ma'ruf, Arya Sinulingga, data-data yang disuguhkan kubu Prabowo itu tidak valid sama sekali”. (judul berita Kubu Jokowi Buka 4 Kejanggalan Data Kecurangan Versi Kubu Prabowo)

Berdasarkan kutipan di atas jelaslah wartawan memihak aktor. Keberpihakan wartawan dapat dilihat dari penyebutan nama aktor. Menjatuhkan pelaku dengan mengatakan bahwa datadata kubu Prabowo tidak valid sama sekali. Wartawan menuliskan secara jelas agar terlihat netral tetapi dari beberapa aspek dan opini yang disampaikan jelas wartawan tidak netral sepenuhnya, sehingga dari beberapa berita tentang pilpers 2019 lebih banyak menjatuhkan satu pihak demi membuat citra baik pihak lain.

\section{Simpulan}

Berdasarkan temuan penelitian dan pembahasan dapat disimpulkan bahwa bentuk teori inclusioan Leeuwen yang ditemukan dalam delapan berita politik tentang Pilpers 2019 media massa online Tempo. Co edisi Mei 2019 sebagai berikut (1) penggunaan teori objektivasi (Obj)abstraksi (Abs) Leeuwen yang ditemukan dalam media massa online Tempo. Co edisi Mei 2019 berjumlah 14 kalimat, (2) penggunaan teori nominasi (Nom)-kategorisasi (Kat) Leeuwen yang ditemukan dalam media massa online media massa online Tempo. Co edisi Mei 2019 berjumlah 20 kalimat, (3) penggunaan teori nominasi (Nom)-identifikasi (Inden) Leeuwen yang ditemukan dalam media massa online Tempo. Co edisi Mei 2019 berjumlah 10 kalimat, (4) penggunaan teori asimilasi (Asi)-individualisasi (Indiv) Leeuwen yang ditemukan dalam media massa online Tempo. Co edisi Mei 2019 berjumlah 15 kalimat, dan (5) penggunaan teori asosiasi (Aso)disosiasi (Dis) Leeuwen yang ditemukan dalam media massa online Tempo. Co edisi Mei 2019 berjumlah 7 kalimat. 
Jurnal Gramatika: Jurnal Penelitian Pendidikan Bahasa dan Sastra Indonesia

(P-ISSN: 2442-8485) (E-ISSN: 2460-6316)

Vol. 5 No. 2. October $2019(236-251)$

http://ejournal.stkip-pgri-sumbar.ac.id/index.php/jurnal-gramatika/index

Berdasarkan hasil temuan dan pembahasan dapat disimpulkan dalam menulis berita kriminal secara keseluruhan wartawan berpihak kepada aktor atau pelaku. Keberpihakan wartawan kepada pelaku dapat dilihat dari cara wartawan memihak actor dengan membeberkan keburukan pihak lain. Selain itu keberpihakan wartawan pada actor juga dilihat sifatnya yang individualis dimana hanya mementingkan satu pihak saja.

\section{Ucapan Terima Kasih}

Pada penulisan artikel ini penulis ingin mengucapakan terima kasih kepada beberapa pihak yaitu kepada dosen pembina mata kuliah jurusan bahasa dan sastra Indonesia Universitas Negeri Padang yang memberikan masukan untuk artikel ini. selanjutnya kepada teman-teman sesame mahasiswa magister pendidikan bahasa dan sastra Indonesia Universitas Negeri Padang yang telah memberikan support dan saran agar artikel ini menjadi lebih baik.

\section{Daftar Pustaka}

Alfianika, Ninit. (2016). Analisis Wacana Kritis Teori Inclusion Theo Van Leeuwen dalam Berita Kriminal Tema Pencurian Koran Posmetro Padang Edisi Mei 2013. Jurnal Gramatika V2. II (33-43).

Baryadi, Praptomo. (2002). Dasar-dasar Analisi Wacana dalam Ilmu Bahasa. Jogjakarta: Pustaka Gondho Suli.

Eriyanto. (2009). Analisis Wacana Pengantar Analisis Teks Media. Yogyakarta: LKiS Yogyakarta.

Fairclough, Norman. (2003). Languange And Power Relasi Bahasa, Kekuatan dan Ideolgi. Malang: Boyan Publishing.

Faridi, Moh. (2014). Analisis Wacana Kritis Teks Berita Politik Dalam Koran Radar Madura Menjelang Pemilu Legislative 2014. Jurnal Nosi. Volume 2 Agustus 2014.

Horvath, Juraj. (2009). Critical Discourse Analysis Of Obama's Political Discourse. Institute Of British And American Studies. Faculty Of Arts.

Jamaludin, Asep. (2016). Pemberitaan Peristiwa Politik Pilgub Sumatera Barat Periode 20162021 Tinjauan Analisis Wacana Kritis Perspektif Teun A Van Dijk Dalam Media Online Portal Harian Singgalang. Junal Pendidikan Bahasa Dan Sastra Indonesia, Vol 5 No 2 September 2016.

Mardalis. (2009). Metode Penelitian Pendekatan Proposal. Jakarta: Bumi Aksara.

Nasab, Sivandi, Zohre, Dowlatabadi And Hamid Reza. (2015). A Critical Discourse Analysis On Newspapers: The Case Study Of Nuclear Program Of Iran. Internasional Journal Of Research Studies In Education. Iran. Volume 5. 
Jurnal Gramatika: Jurnal Penelitian Pendidikan Bahasa dan Sastra Indonesia

(P-ISSN: 2442-8485) (E-ISSN: 2460-6316)

Vol. 5 No. 2. October $2019(236-251)$

http://ejournal.stkip-pgri-sumbar.ac.id/index.php/jurnal-gramatika/index

Queen, Dei Sanasta. (2016). Analisis Wacana Berita Konflik KPK VS POLRI Di Kaltim Post (Edisi Bulan Januari 2015). Junal Ilmu Komunikasi. Vol 4 No 32016.

Rilma, Andre Febra. (2018). Strategi Pemberitaan Di Media Online Nasional Tentang Kasus Tercecernya KTP Elektronik (Analisis Teori Van Leeuwen). Julnal Lingua. Vol XV, No 1 Januari 2019.

Sari, Silvia Permata. (2017). Analisis Wacana Kritis Pada Berita Kriminal Surat Kabar Posmetro Padang. Jurnal Ilmiah UPIYPTK Vol.25.

Silitonga, Frangky Dan Oktavia, Yunisa. (2016). Implementasi Analisis Wacana Kritis Perspektif Leeuwen Dalam Berita Politik Surat Kabar Padang Ekspres Terhadap Pembelajaran Bahasa Berbasis Teks. Jurnal Bahasa Dan Sastra Universitas Putera Batam. Vol 1, No 2, September 2016.

Suharyo, Surono, Mujid F. Amin. (2014). Bahasa Dan Ideologi: Mengungkapkan Ideology Dan Kekuasaan Simbolik Di Balik Penggunaan Bahasa (Kajian Teks Media Melalui Wacana Kritis). Junal Humanika Volume 192014.

Sumarlan, dkk. (2003). Teori dan Praktik Analisi Wacana. Surakarta: Pustaka Cakra.

Tempo .co. (2019). 14 Mei. BPN Klaim Prabowo Unggul 54,24 Persen. https://pilpres.tempo.co/read/1406209/ BPN-klaim-prabowo-unggul-5424-persenkonyol/full?view $=$ ok

Tempo .co. (2019). 15 Mei. Prabowo Menolak Penghitungan Pemilu Curang, Ini Pidato Lengkapnya. https://pilpres.tempo.co/read/1306209/ Prabowo-Menolak-PenghitunganPemilu-Curang-Ini-Pidato-Lengkapnya/full?view=ok

Tempo .co. (2019). 15 Mei. Prabowo Tolak Hasil Pemilu, Jokowi: Serahkan ke KPU. https://pilpres.tempo.co/read/1205823/prabowo-tolak-hasil-pemilu-jokowi-serahkan-ke$\mathrm{kpu} / \mathrm{full}$ ? view $=\mathrm{ok}$

Tempo .co. (2019). 15 Mei. Saksi Prabowo Ditarik, KPU: Hilang Kesempatan Lihat Rekapitulasi. https://pilpres.tempo.co/read/1205739/saksi-prabowo-ditarik-kpu-hilangkesempatan-lihat-rekapitulasi/full?view $=\mathrm{ok}$

Tempo .co. (2019). 16 Mei Kubu Prabowo Serukan Boikot Pajak, Pengamat: Konyol. https://pilpres.tempo.co/read/1206209/kubu-prabowo-serukan-boikot-pajak-pengamatkonyol/full?view $=$ ok 
Jurnal Gramatika: Jurnal Penelitian Pendidikan Bahasa dan Sastra Indonesia

(P-ISSN: 2442-8485) (E-ISSN: 2460-6316)

Vol. 5 No. 2. October $2019(236-251)$

http://ejournal.stkip-pgri-sumbar.ac.id/index.php/jurnal-gramatika/index

Tempo .co. (2019). 16 Mei. Gugatan Diputus Bawaslu, Begini Komentar Kubu Prabowo. https://pilpres.tempo.co/read/1206209/kubu-prabowo-serukan-boikot-pajak-pengamatkonyol/full?view=ok

Tempo .co. (2019). 16 Mei. Kubu Jokowi Buka 4 Kejanggalan Data Kecurangan Versi Kubu Prabowo. https://pilpres.tempo.co/read/1206034/kubu-jokowi-buka-4-kejanggalan-datakecurangan-versi-kubu-prabowo/full?view=ok

Tempo .co. (2019). 16 Mei. Kubu Jokowi Tantang Kubu Prabowo Adu Data C1 Di Kpu. https://pilpres.tempo.co/read/1206038/kubu-jokowi-tantang-kubu-prabowo-adu-data-c1di-kpu/full?view $=$ ok

Tempo .co. (2019). 16 Mei. Kubu Prabowo Serukan Boikot Pajak, Pengamat: Konyol. https://pilpres.tempo.co/read/1206209/kubu-prabowo-serukan-boikot-pajak-pengamatkonyol/full?view $=$ ok

Ulum, Omer Gokhan. (2016). Newspaper Ideology: A Critical Discourse Analysis Of News Headlines On Syrian Refugees In Published Newspaper. International Periodical For The Languages, Literature And Historis Of Tukish Or Turkic. Volume 11/15 Summer 2016. 